\title{
LAW AND DEVELOPMENT IN LATIN AMERICA
}

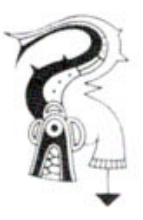

Published for the UCLA LATIN AMERICAN CENTER as Volume 28 in the UCLA LATIN AMERICAN STUDIES SERIES Series editor: Johannes Wilbert 


\section{BOOKS PUBLISHED BY THE UNIVERSITY OF CALIFORNIA PRESS IN COOPERATION WITH THE UCLA LATIN AMERICAN CENTER}

1. Kenneth Karst and Keith S. Rosenn, Law and Development in Latin America: A Case Book. Latin American Studies Series Volume 28, UCLA Latin American Center. 1975.

2. James W. Wilkie, Michael C. Meyer, and Edna Monzón de Wilkie, eds., Contemporary Mexico: Papers of the IV International Congress of Mexican History. Latin American Studies Series Volume 29, UCLA Latin American Center. 1975.

3. Arthur J. O. Anderson, Frances Berdan, and James Lockhart, Beyond the Codices: The Nahua View of Colonial Mexico. Latin American Studies Series Volume 27, UCLA Latin American Center. 1976.

(Except for the volumes listed above, which are published and distributed by the University of California Press, Berkeley, California 94720, all other volumes in the Latin American Studies Series are published and distributed by the UCLA Latin American Center, Los Angeles, California 90024.) 


\title{
LAW AND DEVELOPMENT IN LATIN AMERICA A Case Book
}

\author{
Kenneth L. Karst \\ Professor of Law, \\ University of Califormia, Los Angeles
}

\section{Keith S. Rosenn}

Professor of Law,

Ohio State University 
University of California Press Berkeley and Los Angeles, California University of California Press, Ltd. London, England

Copyright (C) 1975 by The Regents of the University of California ISBN: 0-520-02955-0

Library of Congress Catalog Card Number: 74-30525

Printed in the United States of America 
To Smiley and Silvia who were patient 
